\title{
Assessing Stock Return: \\ Findings from Consumer Goods Industry in Indonesia
}

\author{
Fitria Mandaraira \\ Said Muniruddin \\ Department of Accounting, \\ Faculty of Economics - Syiah Kuala University, \\ Darussalam, Banda Aceh 23111, Indonesia \\ Coorresponding Author: \\ reira.61@gmail.com \& saidmunir@fe.unsyiah.ac.id
}

\begin{abstract}
This study aims to determine the impact of earnings per share (EPS), dividend payout ratio (DPR), debt to equity ratio (DER), and investment opportunity set (IOS) on stock return. Population of this study is consumer goods industry sector companies listed on Indonesia Stock Exchange (IDX). The total sample was taken compromising 17 companies within a period from 2010-2013, by using purposive sampling method. The data used are secondary data and analytical methods use is regression analysis test tools. The results of this study showed that there are no impacts of earnings per share, dividend payout ratio, debt to equity ratio, and investment opportunity set partially and simultaneously on stock return on the consumer goods industry sector companies. The results of this study mostly influenced by the performance of consumer goods industry sector companies that have high stability and resistant towards crisis.
\end{abstract}

Key words: Earnings per share, dividend payout ratio, debt to equity ratio, investment opportunity set, stock return.

\begin{abstract}
Abstrak
Penelitian ini bertujuan untuk melihat pengaruh earnings per share (EPS), dividend payout ratio (DPR), debt to equity ratio (DER), dan investment opportunity set (IOS) terhadap stock return. Populasi dalam studi ini adalah industri barang konsumsi Indonesia yang terdaftar pada Bursa Efek Indonesia (BEJ). Total sampel yang terpilih melalui metode purposive sampling berjumlah 17 perusahaan, dalam masa pengamatan 2010-2013. Data-data yang digunakan adalah data sekunder. Sedangkan metode analisis menggunakan model regresi.
\end{abstract}


Hasil studi menunjukkan bahwa tidak ada pengaruh baik secara parsial maupun simultan dari earnings per share (EPS), dividend payout ratio (DPR), debt to equity ratio (DER), dan investment opportunity set (IOS) terhadap stock return pada sector industri barang konsumsi di Indonesia. Hasil ini memberikan gambaran bahwa kinerja perusahaan-perusahaan pada sektor ini punya stabilitas tinggi termasuk terhadap goncangan krisis.

Kata Kunci: Earnings Per Share (EPS), Dividend Payout Ratio (DPR), Debt to Equity Ratio (DER), Investment Opportunity Set (IOS), stock return.

\section{A. Introduction}

Capital market is a media of funding for companies or other institutions such as government, and an investor. It is also a market for a various long-term (more than one year) financial instruments that can be traded such as obligations, stocks, mutual fund and so on. An investor needs to be aware about a company conditions before making decisions to buy its stocks. This is because the stock values represent the value of a company so that the investor can get better conception toward the company's abilities to grow and develop in the future.

There are five kinds of ratio analysis that is generally used in analyzing the financial statements: liquidity ratios, leverage ratios, profitability ratios, asset utilization ratios, and market measure ratios. They represent all the data in financial statements that needed to be evaluated and compared. These factors can be gathered from EPS (Earnings Per Share), DPR (Dividend Payout Ratio), DER (Debt to Equity Ratio), and IOS (Investment Opportunity Set). These indicators are used in this research as variables and to be tested to see their influence on stock return.

As elements which influence stock return, the indicators mentioned are needed by investors to consider for any investment decisions in order to achieve the objectives of investing. The main objective in investing activities is stock return. Stock return is an excess of the stock selling price to the stock buying price.

The certainty of company's performance and the ability of a company to increase profit and expand the business are the factors that will attract investors to do an investment. The stability of performance shows the certainty of future return. Indonesian consumer goods industry companies sector is one of the sectors that shows the stability and known to be resistant to the crisis occurred. In times of crisis, the movement of its stock performance does come down, but not so significant. Then, the performance of consumer goods companies may be able to recover quickly and have positive prospect (Aziz: 2014). Besides, this sector has the ability to develop their product faster through various innovation and wider market expansion than other sectors. Based on the explanation above, the researcher is interest to study the consumer goods industry sector as the object of this research. 
Several researches about stock return had been conducted, and shown different results. A research by Kurninawan (2013) shows that DER has no influence on stock return while ROE, ROA, and EPS have influence on stock return. Simultaneous regression analysis results obtained shows that EPS, DER, ROA, ROE, simultaneously effect on stock returns. It is different from the research done by Bowen et al (1986) who found that EPS has negative influence on stock return and Arista (2012) who found that there is no influence of EPS on stock return. It is similar to a research done by Hermawan (2012) who found that DER has significant influence and negative on stock return.

Puspitasari and Purnamasari (2013) have conducted a research with the result that DPR has no significant effects on stock return. This result is different with the finding from Carlo (2014) which shows that DPR has positive influence on stock return. Meanwhile, a research is done by Solechan (2009) on IOS influence on stock return, shows that the IOS has no influence on stock return. While Gul, Leung, and Srinindhi (2000) and Fanani (2006) have proven that there is positive influence of IOS and stock return.

Based on the explanation above the purpose of the research is to test both partially and simultaneously the impact of earnings per share, dividend payout ratio, debt to equity ratio, and investment opportunity set on stock return (empirical study on consumption goods industries listed on Indonesia stock exchange for the year 2011-2013).

\section{B. Literature Review}

There are four independent variables in this research, they are earnings per share, dividend payout ratio, debt to equity ratio, and investment opportunity set. According to Darmadji and Fakhruddin (2001) EPS is a ratio that shows how much the return that the investors or shareholders get for each share. The higher EPS of a company will have impact increasing the stock return that investors obtained, and conversely. The higher EPS shows that the company has positive prospect through the increasing of earnings and it will be more likely to increase gain the investors have on its stocks. According to Libby and friends (2004:712) EPS can

computed as follows:

According to Sutrisno (2005) Dividend Payout Ratio is the percentage of the profits distributed as dividends, while the rest portion of the profits available to be invested back into the company as retained earnings. The greater DPR 
will increase stock returns, and vice versa. This theory is supported by Carlo (2014) who found that DPR has positive significant influence on stock return. The formula of DPR is as follow:

DER (Debt to Equity Ratio) is the ratio of corporate debt to total capital. According to Shiddiqui (2010:670) DER is calculated to judge the long-term financial policy of the business. This ratio establishes relationship between longterm loans and owner's funds. According to Bringham and Houston (2006: 17), the higher risk because of the use of more debt will tend to lower the price of the stock. Investors need to pay attention to the health 
of the company through a comparison between equity and loan capital. DER can be computed as follow:

$$
D E R=\frac{\text { Total Liabilities }}{\text { Owner's Equity }}
$$

IOS also can be defined as the feasible set of risks and returns which is expected and available from a set of risky assets, unrestricted by an assets pricing model (Knight, 2002:229). IOS is unobservable and can only be approximated by proxy variables (Belkoaoui, 2002:6). It also stated that proxy IOS used in accounting and finance are classified into 3 types.

IOS serves as the basis for determining the classification of growing or not growing. The value of the investment opportunity is the present value of the options the company to make an investment in the future. According to Kole (1991), the value of IOS depend on the expenses specified in the management of the future which currently investment options are expected to generate returns, is greater than the cost of capital and can generate profits. The greater IOS means the greater investment that the company invests in the next period which would provide a good impact on the sale of stocks and certainly will increase stock returns. IOS can be computed as follow:

$$
M B V A=\frac{\text { Asset }- \text { Total Equity }+(\text { number of share outstanding } x \text { closing price })}{\text { Total assets }}
$$

Dependent variable will be used in this research is stock return. According to Ang (1997) stock return is the rate of profit that obtained by the investors on the investment of the stock. The stock price that is used in this research is closing price. Closing price here means the closing price of a stock at the end of december for each period. Stock return can be formulated as follows:

$$
R t=\frac{P_{(t)}-P_{(t-1)}}{P_{(t-1)}} \quad \begin{aligned}
& \mathrm{Rt}=\text { Stock return at } \mathrm{t} \text { period } \\
& \mathrm{P}(\mathrm{t})=\text { Stock price at } \mathrm{t} \text { period } \\
& \mathrm{P}_{(\mathrm{t}-1)}=\text { Stock price at } \mathrm{t}-1 \text { period }
\end{aligned}
$$
follows:

Based on the theories mentioned, the hypothesis of this research are as H1: EPS has significant influence on stock return on consumer goods industry companies listed on Indonesia Stock Exchange.

$\mathrm{H} 2$ : DPR has significant influence on stock return on consumer goods industry companies listed on Indonesia Stock Exchange. 
H3: DER has significant influence on stock return on consumer goods industry companies listed on Indonesia Stock Exchange.

H4: IOS has significant influence on stock return on consumer goods industry companies listed on Indonesia Stock Exchange.

H5: EPS, DPR, DER, and IOS simultaneously have significant influence on stock return on consumer goods industry companies listed on Indonesia Stock Exchange.

\section{Research Method}

The population of this research is the consumer goods industry sector companies listed in Indonesia stocks exchange. The total of the companies that listed on the consumer goods industry sector is 35 companies. The method that is used in choosing the sample is purposive sampling method. Total sampling in this research is 17 companies that are chosen based on criteria that the companies consistently provide information about eps, dpr, der, and ios for the three consecutive years.

Table 1: List of Samples

\begin{tabular}{|c|l|l|}
\hline No & Stock Code & Security Name \\
\hline 1 & DLTA & PT. Delta Djakarta Tbk \\
\hline 2 & ICBP & PT. Indofood CBP Sukses Makmur \\
\hline 3 & INDF & PT. Indofood Sukses Makmur Tbk \\
\hline 4 & MLBI & PT. Multi Bintang Indonesia Tbk \\
\hline 5 & MYOR & PT. Mayora Indah Tbk \\
\hline 6 & ROTI & PT. Nippon Indosari Corpindo Tbk \\
\hline 7 & GGRM & Gudang Garam Tbk \\
\hline 8 & HMSP & Handjaya Mandala Sampoerna Tbk \\
\hline 9 & DVLA & Darya Vari Laboratoria Tbk \\
\hline 10 & KAEF & Kimia Farma (Persero) Tbk \\
\hline 11 & KLBF & Kalbe Farma Tbk \\
\hline 12 & MERK & Merck Indonesia Tbk \\
\hline 13 & SQBB & Taisho Pharmaceutical Indonesia Tbk \\
\hline 14 & TSPC & Tempo Scan Pasific Tbk \\
\hline 15 & MRAT & PT. Mustika Ratu Tbk \\
\hline 16 & TCID & PT. Mandom Indonesia Tbk \\
\hline 17 & UNVR & PT. Unilever Indonesia Tbk \\
\hline
\end{tabular}

The data will be used in this research is secondary data. According to Sekaran and Bougie (2010:183) secondary data is the information that gathered from the source that already exist and found by someone. It is not conducting by the researcher directly in the current study. The secondary data can be internal or external to the organizations and can be accessed through the internet or 
published information or recording. The related data are acquired from Indonesia stock exchange historical data, website, and related literature study of article, papers, and previous thesis.

In order to analyze data in this research, the researcher uses several analysis methods. Classical assumptions methods is used in order to show the validity of research, and to avoid bias relationship and data redundancy. Besides, multiple regression analysis method is used to study the influences that exist within variables. Multiple regression analysis can be computed as follows:

$$
\mathbf{Y}=\mathbf{a}+\mathrm{b}_{1} \mathrm{X}_{1}+\mathrm{b}_{2} \mathrm{X}_{2}+\mathrm{b}_{3} \mathrm{X}_{3}+\mathrm{b}_{4} \mathrm{X}_{4}+\mathrm{e}
$$

Hypothesis testing is used in order to get the judgment whether the hypothesis are accepted or rejected. Hypotheses testing is done by two kind of tests, partial test ( $\mathrm{t}$ - test) and simultaneous test. The T-test aims to determine the partial relationship between independent variable and dependent variable. It is used to see the influence of independent variable towards dependent variable in regression model by comparing the value of significant $t$ (Sig. T) with the significant level $(\alpha=0.05)$. The criteria's in T-test are as below; H01 : $\beta 1=0$; it means that the EPS does not influence the stock return.

Ha1: $\beta 1 \neq 0$; it means that the EPS influences the stock return.

H02: $\beta 2=0$; it means that the DPR does not influence the stock return. Ha2: $\beta 2 \neq$ 0 ; it means that the DPR influences the stock return.

H03: $\beta 3=0$; it means that the DER does not influence the stock return.

Ha3: $\beta 3 \neq 0$; it means that the DER does influences the stock return. H04: $\beta 4=0$; it means that the IOS does not influence the stock return. Ha4: $\beta 4 \neq 0$; it means that the IOS does influences the stock return. The criteria for accepting or rejecting the hypothesis are as follow:

If $\beta \mathrm{i}(\mathrm{i}=1,2,3,4)=0: \mathrm{H}_{0}$ is accepted; If $\beta \mathrm{i}(\mathrm{i}=1,2,3,4) \neq 0: \mathrm{H}_{0}$ is rejected. 
F-test is applied to determine whether there is relationship between set of independent variable and dependent variable simultaneously. The criteria used in F test are as below:

Ho: $\beta 1=\beta 2=\beta 3=\beta 4=0$, means that EPS, DPR, DER, and IOS simultaneously do not influence the stock return.

Ha: $\beta 1 \neq \beta 2 \neq \beta 3 \neq \beta 4 \neq 0$, means that EPS, DPR, DER, and IOS simultaneously influence the stock return.

The criteria for accepting or rejecting the hypothesis are as follow: If $\beta \mathrm{i}$ ( $\mathrm{i}=$ $1,2,3,4)=0: \mathrm{H} 0$ is accepted; If $\beta \mathrm{i}(\mathrm{i}=1,2,3,4) \neq 0: \mathrm{H} 0$ is rejected.

Another test that is conducted to analyze the data is coefficient determinant. The results of coefficient determination show how much the dependent variable can be explained by the independent variables (Santoso, 2004:167). In this study the multiple linear regression of each variable is the Earning Per Share, Dividend Payout Ratio, Debt to Equity Ratio, and Investment Opportunity Set impact the dependent variable is stock return represented by $\mathrm{R}^{2}$ to determine the coefficient of determination or how much influence on the stock return. The amount of the coefficient of determination is 0 to 1 .

\section{Results and Discussions}

Table 2

Hypotheses Test Result

\begin{tabular}{|c|c|c|c|c|c|c|}
\hline \multirow[t]{2}{*}{ Moc } & & \multicolumn{2}{|c|}{ Unstandardized Coefficients } & $\begin{array}{l}\text { Standardized } \\
\text { Coefficients }\end{array}$ & \multirow[b]{2}{*}{$t$} & \multirow[b]{2}{*}{ Sig. } \\
\hline & & $\mathrm{B}$ & Std. Error & Beta & & \\
\hline \multirow[t]{5}{*}{1} & (Constant) & .335 & .490 & & .684 & .497 \\
\hline & LnEPS & .006 & .032 & .031 & .173 & .863 \\
\hline & LnDPR & .034 & .114 & .053 & .295 & .770 \\
\hline & DER & .074 & .104 & .113 & .711 & .481 \\
\hline & LnIOS & -.020 & .030 & -.100 & -.680 & .500 \\
\hline
\end{tabular}

a. Dependent Variable: LnRETURN

The result of statistical testing (t-test) showed that there is no impact of Earnings per share on stock return. This result consistent with the results of research conducted by Bowen et al (1986) and Arista (2012), who also found that Earnings Per Share has no impact on stock return. The regression coefficient of Earnings per Share is positive and the value is 0.173 . It means that Earnings per Share does not have impact on stock return, because the t-test $>0.05$.

The result that was not significant between variable Earnings per share and stock return is possibly happened due to the rate of the profit that is reflected on EPS is relatively low. This condition makes an investor who expect high return to hold back or not going to invest in consumer goods sector companies. Besides, the condition of consumer goods sector companies that are resistant towards the crisis make the movements of stock prices were not so 
significant compared to previous year. In result, the returns were not changes significantly. Means that the returns did not change so much even though the over the Earnings per share changed. Even though this sector is pledge, but it is not so profitable for the short-time period.

Statistical testing result by t-test showed that the Dividend Payout Ratio (DPR) does not have impact on stock return on consumer goods industry sector companies. Regression coefficient of DPR is positive and the value is 0.29 . As the value is bigger than 0.05 , it can be concluded that DPR does not have impact on stock return. This result is consistent with the result of research conducted by Puspitasari and Purnamasari (2013), who found that DPR does not have significant effect on stock return.

DPR defines the amount of dividend that the investors get for each share compare to the earnings that the company makes for each shares. Despite it provides information for investors, based on the result of this study statistical testing DPR does not have impact on the stock return. In Indonesia, the amount of dividend that will be distributed to investors is decided by shareholders who hold majority of the shares.

Usually, there is only small amount of profit that will be distributed as dividend to the shareholders. Especially, for companies that rely much on its earnings for operational activities. DPR is also influenced by the management policy of the company and it is not routinely distributed.

The results of statistical testing by t-test showed that the Debt to Equity Ratio (DER) does not have significant impact on stock return. This results consistent with research conducted by Kurniawan (2013), who also found that the DER has no influence on stock return. The regression coefficient of DER is positive and the value is 0.711 . This means that DER could not be used to predict return in the future. The high DER of a company means that the company has bad performance, because the company uses a lot of long-term liabilities to fund its operational activities. It causes the risk that will be borne by investors is bigger.

An investor will avoid to invest in the company with high DER. Longterm creditors prefer lower DER to higher because it shows bigger amount of total assets which is funded by the owner equity and the smaller risk that the investor will bear. Besides, DER value did not change much for the next year and the next two years on consumer goods sector industry companies and the changes of the DER is not followed by stock price movements so that the return is not affected by it.

Based on the result of statistical testing by t-test, it showed that there is no impact of Investment Opportunity Set as independent variable on stock return as dependent variable. This result is consistent with the result of a research conducted by Solechan (2009) who found that there is no influence of IOS on stock return. The regression coefficient of IOS is negative and the value is 
0.680. Besides the changes of IOS's value is not followed by the stock prices and return. This means that IOS does not have impact on stock return.

Market to book value asset is a proxy of IOS that was used on this research to defined IOS. The result of this research showed that company's growth that is represented by IOS cannot be used to predict stock return. In another way, the growth value of consumer goods sector companies does not influence the stock return. However, as a sector that provides the consumption goods, consumer goods industry sector companies has potential to keep growing and provide return for the investor. Besides, the stability and resistance feature make the investor can expect to generate returns and are willing to invest in this sector even though the IOS value does not represent stock return.

Table 3

Model Summary

\begin{tabular}{|l|r|r|l|l|r|}
\hline Model & $R$ & R Square & $\begin{array}{l}\text { Adjusted R } \\
\text { Square }\end{array}$ & $\begin{array}{l}\text { Std. Error of the } \\
\text { Estimate }\end{array}$ & Durbin-Watson \\
\hline 1 & $.159^{\circ}$ & .025 & -.059 & .37979 & 1.900 \\
\hline
\end{tabular}

a. Predictors: (Constant), IOS, DER, DPR, EPS

b. Dependent Variable: RETURN

The result of regression analysis showed that the coefficient of determination or R2 of stock return is $2.5 \%$. Whereas if the R-Square is getting close to 0 , it means that the independent variable is have poor influence on the dependent variable.

\section{Conclusions}

Based on the test that has been conducted, all the independent variables do not have impact on the independent variable both partially and simultaneously. It means that all the hypotheses are rejected and cannot be used as indicators to predict future stock return in consumer goods industry companies.

The limitations of this study are: (1) this study uses only four independent variables that related to the companies directly; (2) the object of this study is only consumer goods industry sector companies, so that the results cannot be used as a generalization to different objects; (3) the data used in this study only three years.

Suggestions for future research: (1) research can be conducted by adding more variables; (2) research can be conducted in different industries with more number of companies being sampled; (3) research can be conducting by extending the time of study for more than three years. 


\section{References}

Ang, Robert. 1997. Pasar Modal Indonesia. Jakarta: PT Mediasoft Indonesia.

Arista, Desy. 2012. Analisis Faktor-Faktor yang Mempengaruhi Return Saham. Jurnal Ilmu Manajemen dan Akunatnsi Terapan. 3(1): 1-15.

Azis, Royan. 2014. Mari Intip Saham Sektor Konsumsi yang Menarik.Dapat di akses di $<$ http://www.seputarforex.com $>[05 / 03 / 15]$

Belkaoui, R. A. 2002. Multinationaity: Earnings, Efficiency, and Market Considerations. Westport: Greenwood Publishing Group Inc.

Bowen, R., D. Burgstahler, \& L. Daley. 1986. Evidence on the Relationship Between Earning and Various Measures Cash Flow. The Accounting Review. 61(4): 713-725.

Bringham, E. F., \& J. F. Houston. 2006. Dasar-dasar Manajemen Keuangan. Edisi 10. Jakarta: Salemba Empat.

Carlo, M. A. 2014. Pengaruh Return on Equity, Dividend Payout Ratio, dan Price to Earning Ratio pada Return Saham. E-jurnal Akuntansi Universitas Udayana. 7(1): 150-164.

Darmadji, T., \& Fakhruddin. 2001. Pasar Modal di Indonesia, Edisi 3. Jakarta: Salemba Empat.

Fanani, Z. 2006. Manajemen Laba: Bukti Dari Set Kesempatan Investasi, Utang, Kos Politis, dan Konsentrasi Pasar pada Pasar yang Sedang Berkembang. Simposium Nasional Akuntasi 9 Padang.

Gul, F. A., S. Leung, \& B. Srinidhi. 2000. The Effect of Investment Opportunity Set and Debt Level on Earnings-Returns Relationship and the Pricing of Discretionary Accruals. AAANZ Conference and Accounting Seminars at City University of Hong Kong, Chinese University of Hong Kong, Rutgers University and State University of New York. 1-36.

Hermawan, Dedi A. 2012. Pengaruh Debt to Equity Ratio, Earning Per Share dan Net Profit Margin Terhadap Return Saham. Management Analysis Journal. 1(5): 1-7.

Knight, J., \& S. Satchell. 2002. Performance Measurement in Finance. Oxford: Butterworth- Heinemann.

Kole, S. R. 1991. A Cross-sectional Investigation of Managerial Compensation from an Exante Perspective. University of Rochester working paper.

Kurniawan, Yohanes J. 2013. Analisis Pengaruh Earning Per Share (EPS), Debt to Equity Ratio (DER), Return on Asset (ROA), Return on Equity (ROE) Terhadap Return Saham. Dapat di akses di <http://www.stikstarakanita.ac.id/publikasi.html $>[29 / 1 / 15]$ 
Libby, R., Libby P. A., \& Short D. G. 2010. Financial Accounting. New York: McGraw-Hill.

Puspitasari, A., \& L. Purnamasari. 2013. Pengaruh Perubahan Dividend Payout Ratio dan Dividend Yield Terhadap Return Saham pada Perusahaan Manufaktur di BEI. Journal of Business and Banking. 3(2): 213-222.

Santoso, Singgih. 2004. Buku Latihan SPSS Statistik Multivariat. Jakarta: Elex Media Komputindo.

Sekaran, U., \& R. Bougie. 2010. Research Methods for Business. United Kingdom: John Wiley \& Sons.

Shiddiqui, A. S. 2010. Comprehensive Accounatncy XII. New Delhi: Laxmi Publications Ltd.

Solechan, Achmad. 2009. Pengaruh Earning, Manajemen Laba, IOS, Beta, Size, dan Rasio Hutang Terhadap Return Saham Pada Perusahaan yang Go Public di BEI. STMIK HIMSYA Semarang.

Sutrisno. 2005. Manajemen Keuangan Teori, Konsep, dan Aplikasi. Yogyakarta: Ekonisia. 